STUDIES IN CULTURE POPULAR

\section{The BBC and}

national identity

in Britain, 1922-53

THOMAS HAJKOWSKI

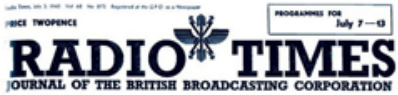

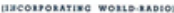

'The Land

\section{We Defend'}

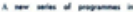

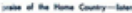
a thenter ate.

\section{ALSO neS WEEK}

'Ropert of Hentabs"

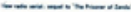

'Forty-Second Street"

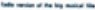

Mrlatide Rujol

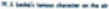

The Wealern Brethen

\& thitus ins

"Keit in the Antaretic"

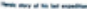

Thoma siligh ât. kowski chesterhive. cora wathould ad
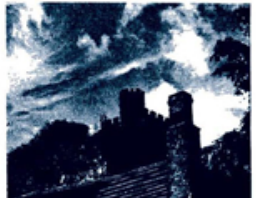

$$
+
$$

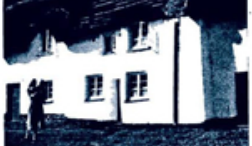




\section{The BBC and national identity in Britain, 1922-53}




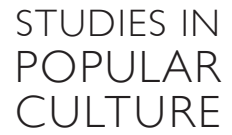

General editor: Professor Jeffrey Richards

Already published

Healthy living in the Alps:

the origins of winter tourism in Switzerland, 1860-1914

Susan Barton

Working-class organisations and popular tourism, 1840-1970

Susan Barton

Leisure, citizenship and working-class men in Britain, I850-I945

Brad Beaven

The British Consumer Co-operative Movement and film, 1890s-1960s

Alan George Burton

British railway enthusiasm

lan Carter

Railways and culture in Britain

lan Carter

Darts in England, 1900-39: a social history

Patrick Chaplin

Relocating Britishness

Stephen Caunce, Ewa Mazierska, Susan Sydney-Smith and John Walton (eds)

History on British television: constructing nation, nationality and collective memory

Robert Dillon

Songs of protest, songs of love: popular ballads in eighteenth-century Britain Robin Ganev

From silent screen to multi-screen:

a history of cinema exhibition in Britain since 1896

Stuart Hanson

Smoking in British popular culture, $1800-2000$

Matthew Hilton

Juke box Britain: Americanisation and youth culture, 1945-60

Adrian Horn

Popular culture in London, c. 1890-1918: the transformation of entertainment Andrew Horrall

Horseracing and the British, 1919-39

Mike Huggins

Working-class taste in Britain, 1930-39: a round of cheap diversions?

Robert James

Amateur operatics: a social and cultural history

John Lowerson

Scotland and the music hall, I850-I9/4

Paul Maloney

Films and British national identity: from Dickens to Dad's Army Jeffrey Richards

Looking North: Northern England and the national imagination

Dave Russell

The British seaside holiday: holidays and resorts in the twentieth century John K.Walton 


\title{
The $\mathrm{BBC}$ and national identity in Britain, 1922-53
}

\section{THOMAS HAJKOWSKI}

\author{
Manchester University Press \\ Manchester and New York
}

distributed exclusively in the USA by Palgrave Macmillan 
Copyright (C)Thomas Hajkowski 2010

The right of Thomas Hajkowski to be identified as the author of this work has been asserted by him in accordance with the Copyright, Designs and Patents Act 1988.

Published by Manchester University Press

Oxford Road, Manchester MI3 9NR, UK

and Room 400, 175 Fifth Avenue, New York, NY I00 I O, USA

www.manchesteruniversitypress.co.uk

Distributed in the United States exclusively by

Palgrave Macmillan, 175 Fifth Avenue, New York,

NY I00।O, USA

Distributed in Canada exclusively by

UBC Press, University of British Columbia, 2029 West Mall,

Vancouver, BC, Canada V6T IZ2

British Library Cataloguing-in-Publication Data

A catalogue record for this book is available from the British Library

Library of Congress Cataloging-in-Publication Data applied for

ISBN 9780719079943 hardback

First published 2010

The publisher has no responsibility for the persistence or accuracy of URLs for any external or third-party internet websites referred to in this book, and does not guarantee that any content on such websites is, or will remain, accurate or appropriate.

Typeset in Adobe Garamond with Gill Sans display by Special Edition Pre-press Services, www.special-edition.co.uk Printed in Great Britain by

CPI Antony Rowe Ltd, Chippenham, Wiltshire 


\section{STUDIES IN POPULAR CULTURE}

There has in recent years been an explosion of interest in culture and cultural studies. The impetus has come from two directions and out of two different traditions. On the one hand, cultural history has grown out of social history to become a distinct and identifiable school of historical investigation. On the other hand, cultural studies has grown out of English literature and has concerned itself to a large extent with contemporary issues. Nevertheless, there is a shared project, its aim, to elucidate the meanings and values implicit and explicit in the art, literature, learning, institutions and everyday behaviour within a given society. Both the cultural historian and the cultural studies scholar seek to explore the ways in which a culture is imagined, represented and received, how it interacts with social processes, how it contributes to individual and collective identities and world views, to stability and change, to social, political and economic activities and programmes. This series aims to provide an arena for the cross-fertilisation of the discipline, so that the work of the cultural historian can take advantage of the most useful and illuminating of the theoretical developments and the cultural studies scholars can extend the purely historical underpinnings of their investigations. The ultimate objective of the series is to provide a range of books which will explain in a readable and accessible way where we are now socially and culturally and how we got to where we are. This should enable people to be better informed, promote an interdisciplinary approach to cultural issues and encourage deeper thought about the issues, attitudes and institutions of popular culture.

Jeffrey Richards 
Thomas Hajkowski - 9781847793010 Downloaded from manchesterhive.com at 04/26/2023 11:50: ๑8AM via free access 